\author{
음식물쓰레기의 가공처리방법별 사료영양소 함량 변화 평가 \\ 및 문제점 개선 방안 \\ 지경수·백용현 · 곽완섭 \\ 건국대학교 자연과학대학 생명자원환경과학부 축산학 전공
}

\title{
Evaluation on Feed-Nutritional Change of Food Waste According to Different Processing Methods and Trouble-shooting Strategy
}

\author{
K. S. Jee, Y. H. Baik and W. S. Kwak
}

Animal Science, School of Life Resource and Environmental Science, College of Natural Sciences, Konkuk University, Danwol-dong 322, Chung-Ju, Chung-Buk, Korea 380-701

\begin{abstract}
This study was conducted to introduce recycling procedures of food waste (FW) as feed according to the dehydration, semi-dehydration fermentation and liquid fermentation methods through the on-site survey of companies related, to trace physico-chemical components and nutritional losses depending upon the processing stage for each method and finally to suggest more desirable methodology for the efficient utilization of FW as animal feed. For the dehydration method, dewatering of $\mathrm{FW}$ alone reduced $(\mathrm{P}<0.05)$ moisture (approximately 10\%) and ether extract contents and increased $(\mathrm{P}<0.05)$ fiber contents. Dewatering and subsequent dehydration of $\mathrm{FW}$ decreased $(\mathrm{P}<0.05)$ contents of ether extract, limiting amino acids such as lysine, methionine and histidine, pepsin digestibility of protein by half, and $\mathrm{NaCl}$ content by $40 \%$, increased $(\mathrm{P}<0.05)$ contents of fiber, crude ash, $\mathrm{Ca}$ and $\mathrm{P}$, and did not alter $(\mathrm{P}>0.05)$ pH. The semi-dehydration fermentation method of $\mathrm{FW}$ did not affect $(\mathrm{P}>0.05)$ the chemical components, pepsin digestibility of protein, $\mathrm{pH}$ and $\mathrm{NaCl}$ content. For the liquid fermentation method, pasteurization and fermentation of $\mathrm{FW}$ decreased $(\mathrm{P}<0.05)$ contents of dry matter, ether extract, crude fiber, lysine and $\mathrm{NaCl}$; however, it did not affect $(\mathrm{P}>0.05)$ other chemical components, pepsin digestibility of protein and $\mathrm{pH}$. Among the processing methods, nutrient losses were highest for the dehydration method $(25 \%$ of metabolizable energy loss, $12 \%$ of organic matter loss) and little for the semi-dehydration and liquid fermentation methods. The on-site survey of companies related revealed that the existence of foreign materials in FW products were problematic for all the three companies surveyed, thus it was necessary to develop a more efficient screener. Before feeding $\mathrm{FW}$-containing diets to pigs, high quality of protein and energy feedstuffs needed to be fortified for the dehydration method. For the semi-dehydration fermentation method, the scientific diet formulation technology was required at the initial mixing stage. For the liquid fermentation method, possibly most energetic and proteinaceous feeds needed to be supplemented for the normal animal growth.
\end{abstract}

(Key words : Food waste, Feed, Recycling, Drying, Fermentation, Process)

“본 연구는 충북지역환경관리센터 연구비 지원으로 수행되었음."

Corresponding author : Kwak, Wan-Sup, School of Life Resource and Environmental Science, College of Natural Sciences, Konkuk University, Danwoldong 322, Chung-Ju, Chung-Buk Province, 380-701, Korea. Tel) 82-43-840-3521, Fax) 82-43-851-8675, e-mail) wsk@kku.ac.kr 


\section{I. 서 론}

우리나라에서는 2003년에 총 416만 톤의 음 식물류 쓰레기가 발생되었으며(환경부, 2004), 이의 경제적 가치는 최소한 15 조원 이상인 것 으로 알려져 있다. 발생되는 음식물쓰레기의 총량의 $25 \%$ 정도는 음식점과 집단급식소에서 발생되며, 이는 가정 원 음식물쓰레기와 비교 해서 이물질이 거의 없고, 사료 영양적 가치가 높아서 가축 사료로의 이용이 용이하며, 년 간 발생되는 최소 100 만 톤 정도를 사료화 방법으 로 처리하였을 때 연간 최소 30 만 톤 정도의 남은 음식물 사료를 자급할 수 있게 되는 셈이 다. 여기에 부재료를 혼합하여 약 100 만 톤 정 도의 발효사료를 제조하여 이용하면 국내에서 연간 소비하는 500 만 톤 규모의 양돈배합사료 의 $20 \%$ 정도를 자급할 수 있는 것으로 계산된 다(곽 등, 2004).

남은 음식물은 국내외적으로 오래 전부터 돼 지나 개 사료로서 이용되어져 왔다. 그러나 이 의 영양 성분은 화학적으로 불안정하여서 빠른 시간 내에 부패되기 때문에(정, 2001) 올바른 방법으로 저장 또는 가공처리 하지 않으면 부 패성 또는 병원성 미생물이 급속도로 자라게 된다. 그러므로 남은 음식물을 가축사료로 이 용하기 전에 반드시 위생적 가공처리를 하여야 하며, 각 국마다 $69 \sim 100^{\circ} \mathrm{C}$ 범위에서 30 분 1 시간 정도 가열 처리할 것을 의무화 하고 있다 (U.S. Congress, 1980; 노, 2001; 농림부, 2001).

가공처리 방법으로는 건식(Westendorf 등, 1998; 남 등, 2000; Kwak과 Kang, 2005)과 습식 가열 방법(서, 1998)이 있으며 건식 가열 방법 에도 함수율 $14 \%$ 이하의 저수분 원료사료 제 조용과 함수율 $30 \pm 10 \%$ 내외의 중수분 발효사 료 제조용(정 등, 2001; 곽 등, 2004))이 있다. 지금까지의 국내외 연구 결과에 의하면 저수분 건식 가열 방법은 건조 비용이 과다하게 소요 되고, 영양적 손실이 상당하며, 동물 생산성이 하락하는 단점이 지적되었다(Westendorf 등, 1998; 남 등, 2000; 정, 2001). 특히 열처리는 고 온에서 발생되는 영양소의 Maillard(갈변) 반응 (Van Soest, 1987)을 유발하여 남은 음식물의
화학적 조성에 영향을 미칠 수 있으며, 실제로 미국의 연구자들(Myer 등, 1999)은 건조한 남은 음식물 단백질의 펩신 소화율은 대두박 단백질 의 것 보다 다소 낮았으며, 이는 남은 음식물 의 고열처리에 따른 갈변 반응에 의해 비소화 성 단백질 함량이 증가한 때문이라고 하였다. 습식 가열 방법은 과다한 액상 사료 공급으로 사료 건물 섭취량 저하로 인한 성장 지체 현상 이 단점으로 지적되기도 하였다(정 등, 1999).

환경적 문제는 차치하고서라도 동물영양학적 차원에서 보면 남은 음식물을 이용한 양질의 사료 생산은 참으로 중요한 과제이다. 국내외 적으로 보도된 남은 음식물 사료 급여 시 나타 난 제한적 요소로는 사료건물 섭취량 저하, 높 은 영양적 변이도, 영양적 불균형, 낮은 영양소 소화율, 성장 지체, 육질 저하(특히 근내지방도 저하), 지방연화 등이 각각 보고된 바 있다(이 1998; 소, 1999; Myer 등, 1999; Chae 등, 2000; Westendorf, 2000; 정, 2001).

지금까지 우리나라에서는 음식물쓰레기의 사 료화 업체들이 많이 생겨나고, 여러 가지 방법 으로 처리하고 있으나, 이들 업체들의 사료화 방법 차이에 따른 직접적인 비교 평가는 이루 어지지 않았다.

따라서 본 연구는 음식물쓰레기의 건식 건 조, 반건식 발효, 습식 발효 사료화 방법별로 대표적 업체를 방문하여 사료 제조 공정을 조 사.소개하고, 사료화 방법별 공정별 음식물쓰 레기의 물리화학적 성분을 추적하고, 영양소 손실율을 비교.평가하며, 사료화 방법별 문제 점을 발굴하여 이의 개선 방안을 최종적으로 제시하기 위하여 실시하였다.

\section{II. 재료 및 방법}

\section{1. 현장 조사 및 시료 채취}

음식물쓰레기 사료화 업체별로 조사한 문제 점을 분석하여 이의 개선 방안을 도출하여 결 과적으로 사료화 방법별로 효과적 가공처리 모 델을 제시하기 위해서 가공처리 방법별로 저수 분 건조 사료화 처리업체인 'A' 업체, 반건식 
발효 사료화 처리업체인 'B' 업체, 습식 사료화 처리업체인 ' $\mathrm{C}$ ' 업체 등 대표적 회사를 자체 선 정하여 사료화 현장을 직접 방문하여 사료화 공정 단계별로 현황을 조사, 분석하였고, 또한 각각의 사료제조 방법에 따라 공정별로 시료를 채취하여 음식물쓰레기 또는 그 혼합물의 이물 질 및 물리화학적 성분 변화를 추적하였다. 업 체의 기밀 보존을 위해서 구체적인 업체명은 본문에서는 생략하였다.

현장 방문한 업체별로 음식물쓰레기의 처리 공정 및 음식물쓰레기의 물리적 구성, 최종 제 품의 물리적 성상과 각 처리 공정상의 영양적 손실율, 음식물쓰레기의 사료화 시 보조사료의 사료영양적 이용 프로그램 활용 상의 문제점 및 기계적(음식물쓰레기 처리를 위한 최적의 기계설비 - 영양소 손실을 줄이며, 음식물쓰레 기의 물리적 특성을 고려한 공정 체계) 문제점 등에 대한 조사를 실시하였다.

Table 1에는 건식, 반건식, 습식 사료화 공정 (업체)별로 요약된 처리 과정을 제시하였다. 저 수분 건조 사료화 방법을 이용하는 'A' 업체의 경우, 음식물쓰레기는 탈수, 선별, 파쇄, 건조 과정을 거쳐 처리되며, 처리공정에 따라서, 탈 수 전 음식물쓰레기, 탈수기를 거쳐 선별-파 쇄된 음식물쓰레기(탈수 후 음식물쓰레기), 건 조 과정을 거친 건조물로 나누어 시료를 채취 하여 공정에 따른 물리화학적 변화를 조사하였 다. 시료(약 $2 \mathrm{~kg}$ 씩)는 여름과 초가을(2002년 7 월 18일, 19 일, 9월 2일, 3 일, 4일)에 걸쳐 총 5 회 채취하였다.

음식물쓰레기를 반건식 발효 사료화 방법에 따라 처리하는 'B' 업체의 경우, 음식물쓰레기 는 탈수, 선별, 파쇄, 기존 사료와 혼합, 회전드
럼에서의 멸균 $\left(80^{\circ} \mathrm{C}, 30\right.$ 분 이상 $)$ 및 숙성 과정 (18시간)을 거쳐 처리되며, 음식물쓰레기 혼합 물의 멸균 전과 후, 숙성 후의 단계에서 각각 시료를 채취하였다. 숙성은 윗면이 개방되고, 바닥은 지상에 위치하여 바닥 구멍을 통해 공 기가 자연적으로 통하도록 특수 제작된 나무 상자 (가로 $90 \mathrm{~cm} \times$ 세로 $90 \mathrm{~cm} \times$ 높이 $130 \mathrm{~cm}$ ) 내에서 이루어 졌다. 숙성기간에도 자연 발효 열로 인해 상자 내부온도는 $63 \sim 80^{\circ} \mathrm{C}$ 로 유지되 었다. 혼합사료 제조와 시료 채취(약 $2 \mathrm{~kg}$ 씩)는 가을과 겨울에 걸쳐 5회 시행하였다(2002년 10 월 31, 11월 20일, 21일, 12월 4일, 5일). 음식물 쓰레기 혼합사료는 본 실험실에서 $\mathrm{NRC}$ 돼지 사양 표준(1998)에 입각하여 설계된 비육돈 전 용 완전사료화 프로그램을 이용하여 제조하였 으며, 이용된 기존 사료는 제과부산물, 맥강, 밀기울, 옥분 등이었다.

음식물쓰레기를 습식 사료화 방법에 따라 처 리하는 ' $\mathrm{C}$ ' 업체의 경우, 음식물쓰레기는 1 차 선별, 파쇄, 2차 선별, 멸균, 발효 및 보조사료 혼합 과정을 거쳐 처리되며, 수거된 음식물쓰 레기가 투입되고 중력파쇄를 거친 시점에서 최 초 음식물쓰레기 시료를 채취하였고, 이후 선 별기를 거쳐, 칼날파쇄를 통과하고 자력선별기 를 거친 후, 예열기를 지나, 멸균을 거친, 보조 사료 혼합 전의 액상 음식물쓰레기를 시료로 채취하였다. 약 $2 \mathrm{~kg}$ 씩의 시료를 가을과 초겨 울에 걸쳐(2002년 10월 14일, 15일, 12월 16일, 17 일, 18 일) 총 5 회 채취하였으며, 이상 채취한 모든 시료는 향후 물리화학적 분석을 위해서 $-20^{\circ} \mathrm{C}$ 의 냉동고(Deep Freezer, Ilshin, Korea)에 보관하였다.

Table 1. Processing procedure of food waste depending upon dehydration, semi-dehydration fermentation, and liquid fermentation methods

\begin{tabular}{lll}
\hline \multicolumn{1}{c}{ Dehydration } & \multicolumn{1}{c}{ Semi-dehydration fermentation } & \multicolumn{1}{c}{ Liquid fermentation } \\
\hline \hline 1. Dewatering & 1. Dewatering & 1. $1^{\text {st }}$ screening \\
2. Screening & 2. Screening & 2. Grinding \\
3. Grinding & 3. Grinding & 3. $2^{\text {nd }}$ screening \\
4. Dehydration & 4. Blending with other feeds & 4. Pasteurization \\
& 5. Pasteurization & 5. Fermentation \\
& 6. Aging & 6. Blending with other feeds \\
\hline
\end{tabular}




\section{2. 화학 분석}

신속히 실험실로 옮겨진 채취 시료는 $\mathrm{pH}$ meter (HI 9321, Hanna Instrument, Portugal) 상에서 $\mathrm{pH}$ 를 측정하였고, 냉동된 시료는 해동하여 105 ${ }^{\circ} \mathrm{C}$ 에서 24시간 동안 건조하여 Sample Mill (Cemotec, Tecator, Sweden)을 이용하여 $1 \mathrm{~mm}$ 스크린을 통과하는 크기로 분쇄하여 화학 분석 에 이용하였다. 건물, 조단백질 $(\mathrm{N} \times 6.25)$, 조지 방, 조섬유소, 조회분, $\mathrm{Ca}$, pepsin 소화율, 총 에 너지 등은 $\mathrm{AOAC}(1990)$ 방법에 따라, ash free neutral detergent fiber(NDF), acid detergent fiber (ADF)는 Van Soest 등(1991)의 방법에 따라, phosphorus(P)는 Fiske와 Subbarow(1925)의 방법 에 따라 분석하였다. 가용무질소화합물은 유기 물에서 조단백질, 조섬유소, 조지방을 뺀 값으 로, 비섬유성 탄수화물은 유기물에서 조단백질, $\mathrm{NDF}$, 조지방을 뺀 값으로 구하였다. $\mathrm{Na}$ 및 $\mathrm{Cl}$ 은 atomic absorption spectrophotometer (Varion Techtron Model SpectrAA-300, Australia) 상에서 분석하였다. 필수 및 비필수 아미노산은 $6 \mathrm{~N}$ $\mathrm{HCl}$ 용액에서 가수분해한 시료를 amino acid analyzer(Pharmacia Biotech, England) 상에서 분 석하였다. 가소화에너지는 Noblet과 Perez (1993) 의 공식에 따라, 대사성에너지는 May와 $\operatorname{Bell}(1971)$ 의 공식에 따라 계산하였다.

\section{3. 통계 분석}

통계 분석을 위하여 General Linear Model procedure를 이용하였고, 둘 이상의 평균간 비 교는 Tukey's multiple range test를, 두개 평균간 비교는 Studentized-t test를 이용하여 실시하였 다(Statistix7, 2000).

\section{III. 결과 및 고찰}

\section{1. 가공 처리 방법별 사료 제조 공정 현장 조사}

(1) 건식 사료화 방법

저수분 건조 사료화 처리 공정('A' 업체)의
경우, 음식물쓰레기의 대부분을 중-소도시의 아파트와 공동주택에서 수거하고 있었으며, 수 거 및 운반은 시(市)에서 담당하고 있었다. 음 식물쓰레기는 가정원이 대부분이어서 채소류, 김치류, 과일 껍질 등이 주류를 이루고 있었다. 또한 병뚜껑, 비닐류 등의 이물질이 관찰되었 다.

사료화 현장에 도착한 음식물쓰레기는 지하 저장조에서 하루 정도 저장된 다음 스크류로 끌어 올려져 탈수기로 투입되고 약 30 분 정도 탈수과정을 거친 다음, 선별-파쇄기로 이동한 다. 이동 중에 컨베이어 벨트 상에서 수작업으 로 부피가 큰 이물질들은 1 차 제거된다. 선별 - 파쇄기에서 2 차로 이물질이 제거되고, 파쇄 된 음식물쓰레기는 2차 저장조에 모여진 후 회 전 드럼식 건조기로 이동한다. 여기서 120 150 ${ }^{\circ} \mathrm{C}$ 에서 약 4 시간 정도 간접 가열 방식에 의해 함수율 $10 \%$ 정도로 건조된다. 1 차 저장 중에 발생된 침출수는 따로 분리하여 침출수 저장조 에 모아둔 후 인근의 하수처리장으로 운반하여 처리한다. 생산된 건조 제품은 대부분 비료 원 료로 쓰이거나, 단위가축(개, 오리 등)의 사료로 이용되며, 무상 공급하고 있으나 공급율은 매 우 낮았다. 비료화 시에는 염분이 높아서 단독 사용은 어렵고, 다른 원료와 혼합하여 쓰이고 있었다. 일일 30 톤 정도의 음식물쓰레기를 처 리하며, 전체 투입량 중 약 $20 \%$ 정도인 6 톤 정 도가 건조 제품으로 생산된다.

(2) 반건식 발효 사료화 방법

반건식 발효 사료화 처리 공정('B' 업체)의 경우에도 아파트와 공동주택에서 음식물쓰레기 를 수거하여 처리한다. 이 업체의 반건식 발효 사료화 방법은 원료 음식물쓰레기는 파쇄·선 별을 거친 후 탈수하지 않은 채 수분 조절 및 영양 보충용 보조사료와 자체 설계한 사료 배 합비에 따라 혼합하여 교반기에서 30 분간 교반 된다. 교반 후 rotary drum식 멸균기로 이동시 켜 $80^{\circ} \mathrm{C}$ 에서 30 분 이상 가열하여 멸균시킨다. 멸균 공정을 마친 후 숙성 상자로 옮겨져, 18 시간 동안 호기적 숙성을 거치면 최종 제품이 된다. $500 \mathrm{~kg}$ 기준으로 혼합물을 투입하였을 때 
최종 제품은 약 $430 \mathrm{~kg}$ 정도 생산되었다. 감량 은 $14 \%$ 정도 이었다.

\section{(3) 습식 발효 사료화 방법}

습식 사료화 처리 공정의 경우, 'C' 업체는 일일 50 톤 정도의 아파트, 공동주택, 단독주택, 집단 급식소 원 음식물쓰레기를 수거하여 처리 하고 있었다. 전반적으로 모든 공정이 자동화 시스템으로 운영되고 있었다. 투입된 원료는 중력 파쇄에 의해 1 차로 파쇄 되며, 선별기로 이동하여 선별된 원료는 2차로 칼날 파쇄기(직 경 $5 \mathrm{~mm}$ )를 통과하여 완전 파쇄된다. 이후 자 력선별기로 이동하여 금속 이물질을 걸러내고 예열기 $\left(80^{\circ} \mathrm{C}, 20\right.$ 분 가열 $)$ 를 거쳐 스팀 멸균기 (심부온도 $100^{\circ} \mathrm{C}$ 이하)에서 10 분 정도 멸균한 후, 저장 탱크로 운송되어, 돼지에게 급여 전에 보조사료와 혼합된다. 액상사료를 제조하기 때 문에 침출수 문제나, 건조 시에 발생되는 악취 문제는 없었다. 이물질 배출량은 전체 처리량 의 $10 \sim 15 \%$ 정도의 수준이었고, 액상사료로의 전환율은 $80 \%$ 정도이었다. 다량의 음식물쓰레 기 처리를 위해 대규모의 기계적인 처리 과정 을 거치며 액상이기 때문에 이물질이 많이 발 견되었다.

\section{2. 처리 방법별 음식물쓰레기 또는 혼합물의 물리화학적 성분}

\section{(1) 건식 사료화 방법}

여름과 늦가을에 걸쳐서 현장에서 조사한 음 식물쓰레기(주로 아파트원)의 물리적 성상은 여 름철에는 과일껍질(사과, 수박, 참외, 포도 등), 야채류(파, 양파, 오이, 호박, 가지, 콩나물 등), 곡류(옥수수, 밥, 빵 등), 김치류, 기타(옥수수껍 질, 생선 찌꺼기, 생선 뼈 등), 약간의 이물질 (비닐봉지, 플라스틱 조각, 쇠조각 등) 등으로 구성되어져 있었고, 늦가을 철에는 김장 시기 와 일치하여 수거된 음식물쓰레기는 김치 제조 에 쓰이는 배추와 무 등의 찌꺼기가 주류였으 며, 그 외 과일(귤, 배, 사과, 감 등) 껍질, 견과 류(땅콩, 밤 등) 껍질, 야채(파, 양파, 호박, 콩 나물 등) 찌꺼기 등으로 구성되었다. 이물질로
는 비닐봉지, 플라스틱 조각이 대부분이었으며, 그 외에 우유팩, 병뚜껑 등도 발견되었다. 선별 - 파쇄 후에도 일부의 이물질들은 걸러지지 않 고 그대로 남아 있었다. 사료화시 이물질의 철 저한 선별과정이 필연적으로 요구되었다.

저수분 건조화 시의 공정간 음식물쓰레기의 물리화학적 성분 변화는 Table 2에 제시되어져 있다. 탈수 전과 후의 영양소의 차이는 저장 중 침출수 분리와 탈수공정에 의한 수분 제거 에 따른 것으로 사료되었다. 음식물쓰레기 수 분에 포함된 수용성 영양소는 탈수 시에 함께 빠져나가게 된다. 탈수로 인해 함수율이 약 $10 \%$ 낮아지고 $(\mathrm{P}<0.05)$, 조지방 성분이 줄어들며 $(\mathrm{P}<0.05)$, 섬유소( $\mathrm{NDF}, \mathrm{ADF}$, 조섬유소) 성분은 증가하였다 $(\mathrm{P}<0.05)$.

탈수 전과 비교해서 탈수 후 건조한 음식물 쓰레기(함수율 $10 \%$ 정도)는 유기물과 조지방 성분이 줄어들고 $(\mathrm{P}<0.05)$, 섬유소 $(\mathrm{NDF}, \mathrm{ADF})$ 성분은 증가하였고 $(\mathrm{P}<0.05)$, 조회분 성분 증가 와 함께 $\mathrm{Ca}, \mathrm{P}$ 의 성분도 증가하였다 $(\mathrm{P}<0.05)$. 그러나 조단백질과 가소화 및 대사성 에너지 성분은 높은 변이도로 인해 유의성이 없었다 $(\mathrm{P}>0.05)$. 이러한 유기물의 감소 현상은 장시간 고열처리에 따른 수분 증발과 함께 휘발성 물 질들도 쉽게 증발하기 때문인 것으로 사료되었 다. 육성돈의 $\mathrm{Ca}$ 과 $\mathrm{P}$ 의 요구량은 각각 $0.6 \%$, $0.45 \%$ 이다(NRC. 1998). 본 실험에 이용된 음식 물쓰레기의 $\mathrm{Ca}$ 과 $\mathrm{P}$ 함량(각각 $3.23 \%, 0.64 \%$ )은 요구량 보다 훨씬 높으나, 동물 체내 이용율은 매우 낮기 때문에(Barth 등, 1966) 이의 과다 섭 취로 인한 문제는 미미할 것으로 사료 되었다.

산도 $(\mathrm{pH})$ 에 있어서(Table 2), 음식물쓰레기의 탈수 전과 비교해서 탈수 후와 건조 후에도 $\mathrm{pH}$ 는 유의적 차이가 없었다 $(\mathrm{P}>0.05)$. 탈수 전 음식물쓰레기의 낮은 $\mathrm{pH}$ 는 원료 음식물쓰레기 가 운반 - 저장 중에 상당히 발효가 되었음을 의미한다. 염분 $(\mathrm{NaCl})$ 은 탈수 공정을 거치면서 $40 \%$ 이상 감소하였다 $(\mathrm{P}<0.05)$. 다른 사료와 혼 합하면 염분 농도가 더욱 희석되기 때문에 과 다한 염분 농도로 인한 문제는 해소될 것으로 판단되었다.

음식물쓰레기 원료와 건조 제품의 아미노산 
Table 2. Chemical composition(dry matter basis) of food waste depending upon the processing stage for the dehydration method ${ }^{1)}$

\begin{tabular}{lcccc}
\hline & \multicolumn{3}{c}{ Processing stage } & SE \\
\cline { 2 - 3 } Item $^{2)}$ & $\begin{array}{c}\text { Before } \\
\text { dewatering }\end{array}$ & $\begin{array}{c}\text { After } \\
\text { dewatering }\end{array}$ & $\begin{array}{c}\text { After } \\
\text { dehydration }\end{array}$ & \\
\hline \hline Dry matter (\%) & $19.9^{\mathrm{a}}$ & $29.4^{\mathrm{b}}$ & $89.6^{\mathrm{c}}$ & 1.8 \\
Organic matter (\%) & $86.7^{\mathrm{a}}$ & $81.9^{\mathrm{ab}}$ & $74.8^{\mathrm{b}}$ & 4.0 \\
Crude protein (\%) & 19.8 & 18.0 & 17.7 & 1.2 \\
Neutral detergent fiber (\%) & $24.8^{\mathrm{a}}$ & $34.1^{\mathrm{b}}$ & $30.4^{\mathrm{b}}$ & 1.8 \\
Acid detergent fiber (\%) & $20.0^{\mathrm{a}}$ & $26.8^{\mathrm{b}}$ & $27.3^{\mathrm{b}}$ & 1.3 \\
Crude fiber (\%) & $11.6^{\mathrm{a}}$ & $17.7^{\mathrm{b}}$ & $13.3^{\mathrm{a}}$ & 1.0 \\
Nonfibrous carbohydrates (\%) & $28.3^{\mathrm{a}}$ & $21.2^{\mathrm{b}}$ & $19.4^{\mathrm{b}}$ & 2.1 \\
Ether extract (\%) & $13.8^{\mathrm{a}}$ & $8.6^{\mathrm{b}}$ & $7.3^{\mathrm{b}}$ & 1.0 \\
Nitrogen-free extract (\%) & 41.5 & 37.6 & 36.5 & 2.6 \\
Crude ash (\%) & $13.3^{\mathrm{a}}$ & $18.1^{\mathrm{ab}}$ & $25.2^{\mathrm{b}}$ & 4.0 \\
Calcium (\%) & $2.13^{\mathrm{a}}$ & - & $3.23^{\mathrm{b}}$ & 0.57 \\
Phosphorus (\%) & $0.47^{\mathrm{a}}$ & - & $0.64^{\mathrm{b}}$ & 0.09 \\
Gross energy (Mcal/kg) & 4.514 & 4.464 & 3.840 & 0.256 \\
Digestible energy (Mcal/kg) & 3.391 & 3.407 & 2.870 & 0.241 \\
Metabolizable energy (Mcal/kg) & 3.304 & 3.331 & 2.804 & 0.236 \\
pH & 4.39 & 4.67 & 4.82 & 0.19 \\
NaCl (\%) & $3.69^{\mathrm{a}}$ & $2.13^{\mathrm{b}}$ & $2.21^{\mathrm{b}}$ & 0.33 \\
\hline Means & & & &
\end{tabular}

1) Means of 5 observations.

2) Digestible and metabolizable energy were calculated according to the equations of Noblet and Perez(1993) and May and Bell(1971), respectively.

${ }^{\text {abc }}$ Means with different superscripts within the same row are significantly $\operatorname{different}(\mathrm{P}<0.05)$.

성분 변화는 Table 3에 나타나 있다. 전반적으 로 음식물쓰레기를 탈수, 건조하였을 경우 탈 수 전 음식물쓰레기와 비교해서 총 아미노산 함량이 $9.4 \%$ 감소하였으나, 통계적 유의성은 없었으며 $(\mathrm{P}>0.05)$, 필수아미노산 중 lysine, methionine, histidine 등은 감소하였다 $(\mathrm{P}<0.05)$, 비 필수 아미노산보다도 필수 아미노산이 열처 리에 더 민감하게 반응하는 것으로 나타났다.

음식물쓰레기 단백질의 pepsin 소화율에 있어 서, 원료 음식물쓰레기에 비해 탈수, 건조 후에 는 pepsin 소화율이 반 정도로 감소하였다 $(\mathrm{P}<$ 0.05). 이는 탈수 과정 중 수용성 단백질의 손 실과 건조 공정 중 고열처리에 의해 일어나는 Maillard 반응(Van Soest, 1987) 즉 아미노산과 당의 결합으로 인한 비소화성 물질로의 전환 때문인 것으로 사료되었다. 결과적으로 건조한 음식물쓰레기의 동물 급여 시 체내 단백질 소 화율이 상당히 낮을 것으로 예상되며, 사료 배
합비 설계 시 양질의 단백질 사료를 반드시 보 충하여야 할 것으로 판단되었다.

(2) 반건식 발효 사료화 방법

음식물쓰레기 혼합물의 공정간 화학적 성분 변화는 Table 4 에 나타나 있다. $80^{\circ} \mathrm{C}$ 에서 30 분 이상의 살균 공정과 18 시간 정도의 호기적 숙 성 공정은 양돈용 완전사료용으로 제조된 혼합 발효사료의 화학적 성분 즉 일반 조성분, 단백 질의 pepsin 소화율 및 에너지 성분에 별다른 영향을 미치지 않았다 $(\mathrm{P}>0.05) . \mathrm{Ca}$ 과 $\mathrm{P}$ 성분은 숙성 후에 각각 $0.72 \%$ 와 $0.58 \%$ 로서(Table 미제 시), 육성돈의 $\mathrm{NRC}(1998) \mathrm{Ca}$ 과 $\mathrm{P}$ 의 최소 요구 량인 $0.6 \%, 0.45 \%$ 를 충분히 만족시키는 수준이 었다. 음식물쓰레기 혼합물의 $\mathrm{pH}$ 는 멸균 전 6.0 , 멸균 후 6.2 , 숙성 후 6.1 정도로 공정간 차이는 없었으며, 염분도 멸균 전 $0.95 \%$, 멸균 후 $0.81 \%$, 숙성 후 $0.83 \%$ 로 차이가 없었다 
Table 3. Amino acid contents and pepsin digestibility of food waste according to the processing stage for the dehydration method ${ }^{1)}$

\begin{tabular}{|c|c|c|c|}
\hline \multirow[b]{2}{*}{ Item } & \multicolumn{2}{|c|}{ Processing stage } & \multirow[b]{2}{*}{ SE } \\
\hline & $\begin{array}{c}\text { Before } \\
\text { dewatering }\end{array}$ & $\begin{array}{c}\text { After dewatering \& } \\
\text { dehydration }\end{array}$ & \\
\hline & $\ldots \ldots \ldots \ldots$ & $\begin{array}{llll}\cdots & \% & \cdots\end{array}$ & \\
\hline \multicolumn{4}{|c|}{ Essential amino acids } \\
\hline Lysine & $0.59^{\mathrm{a}}$ & $0.41^{\mathrm{b}}$ & 0.04 \\
\hline Methionine & $0.25^{\mathrm{a}}$ & $0.17^{\mathrm{b}}$ & 0.01 \\
\hline Threonine & 0.68 & 0.57 & 0.05 \\
\hline Isoleucine & 0.62 & 0.55 & 0.03 \\
\hline Valine & 0.78 & 0.69 & 0.04 \\
\hline Leucine & 1.16 & 1.02 & 0.06 \\
\hline Histidine & $0.49^{\mathrm{a}}$ & $0.33^{\mathrm{b}}$ & 0.03 \\
\hline Phenylalanie & 0.76 & 0.70 & 0.02 \\
\hline Arginine & 0.76 & 0.81 & 0.14 \\
\hline \multicolumn{4}{|c|}{ Non-essential amino acids } \\
\hline Aspartic acid & 1.41 & 1.27 & 0.08 \\
\hline Glutamic acid & 2.28 & 2.08 & 0.20 \\
\hline Serine & 0.69 & 0.59 & 0.03 \\
\hline Proline & 0.57 & 0.71 & 0.17 \\
\hline Glycine & 0.93 & 1.02 & 0.07 \\
\hline Alanine & 1.02 & 0.89 & 0.05 \\
\hline Tyrosine & 0.53 & 0.46 & 0.07 \\
\hline Cystine & 0.22 & 0.18 & 0.07 \\
\hline Total amino acids & 13.74 & 12.45 & 0.64 \\
\hline Pepsin digestibility & $76.6^{\mathrm{a}}$ & $41.1^{b}$ & 3.5 \\
\hline
\end{tabular}

1) Based on dry matter.

${ }^{\mathrm{ab}}$ Means with different superscripts with in the same row are significantly $\operatorname{different}(\mathrm{P}<0.05)$.

(Table 미제시). 특히 혼합 발효사료의 염분은 돼지의 $\mathrm{NRC}$ 권장량인 $0.25 \sim 0.5 \%$ (NRC, 1998) 보다는 다소 높았으나, 건조 사료화 방식을 통 해 제조된 음식물쓰레기 단일물 보다는 훨씬 낮은, 양호한 수치에 속하였다. 혼합 발효사료 의 총 아미노산 함량은 $11.2 \%$ 였고, 이중 lysine 함량이 $0.17 \%$ 로서 매우 낮은 것으로 확인되어 (Table 미제시) 혼합 발효사료 급여 시 lysine을 필수적으로 보충하여야 할 것으로 사료되었다.

(3) 습식 발효 사료화 방법

본 습식 발효 사료화 공정에 이용된 음식물 쓰레기의 물리적 성상은 오징어 다리, 조개껍 질, 생선살, 다시마, 생선꼬리, 게껍질, 생선내
장 등과 양파, 당근, 고추, 파, 콩나물, 미역줄 기, 감자, 호박, 육류 등의 찌꺼기와 뼈다귀, 과 일껍질(귤, 사과 등), 김치 찌꺼기 등으로 구성 되어져 있었다. 이중 구성 비율이 가장 높은 것은 김치와 야채류이고, 그 다음으로 육류(생 선류 포함), 과일껍질, 기타 등의 순으로 이루 어져 있었다. 이물질로는 비닐 조각, 쇠 조각 등이 발견되었다.

습식 발효 사료화 공정간 음식물쓰레기의 화 학적 성분 변화는 Table 5에 제시되어져 있다. 멸균 전과 비교해서 멸균 및 발효 후에는 건 물, 조지방 및 조섬유소 성분이 감소하였으나 $(\mathrm{P}$ $<0.05)$ 그 외에는 별 다른 성분 변화는 없었다 $(\mathrm{P}>0.05)$. 건물 감소는 미생물 발효에 의한 수 
Table 4. Chemical compositions(dry matter basis) of food waste mixture according to the processing stage for the semi-dehydration fermentation method ${ }^{1)}$

\begin{tabular}{|c|c|c|c|c|}
\hline \multirow[b]{2}{*}{ Item $^{2)}$} & \multicolumn{3}{|c|}{ Processing stage } & \multirow[b]{2}{*}{ SE } \\
\hline & $\begin{array}{c}\text { Before } \\
\text { pasteurization }\end{array}$ & $\begin{array}{c}\text { After } \\
\text { pasteurization }\end{array}$ & Aged & \\
\hline Dry matter $(\%)$ & 54.7 & 59.9 & 61 & 3.4 \\
\hline Organic matter $(\%)$ & 89.8 & 89.6 & 89.9 & 1.3 \\
\hline Crude protein $(\%)$ & 13.4 & 17.3 & 17.4 & 0.6 \\
\hline Pepsin digestibility (\%) & 82.5 & 80.9 & 80.4 & 2.1 \\
\hline Neutral detergent fiber $(\%)$ & 25.4 & 24.2 & 27.1 & 2.4 \\
\hline Acid detergent fiber $(\%)$ & 14.1 & 14.2 & 15.3 & 0.8 \\
\hline Crude fiber $(\%)$ & 10.2 & 9.9 & 9.8 & 0.9 \\
\hline Nonfibrous carbohydrates $(\%)$ & 39.7 & 40.5 & 40.2 & 2.0 \\
\hline Ether extract $(\%)$ & 7.5 & 7.3 & 7.4 & 0.9 \\
\hline Nitrogen-free extract $(\%)$ & 54.8 & 55.2 & 55.2 & 2.5 \\
\hline Crude ash $(\%)$ & 10.1 & 10.4 & 10.1 & 1.3 \\
\hline Gross energy (Mcal/kg) & 4.422 & 4.262 & 4.167 & 0.196 \\
\hline Digestible energy (Mcal $/ \mathrm{kg}$ ) & 3.210 & 2.984 & 2.966 & 0.349 \\
\hline Metabolizable energy (Mcal/kg) & 3.177 & 2.938 & 2.919 & 0.366 \\
\hline
\end{tabular}

분 발생량 증가에 기인하는 것으로 사료되었 다. 조지방의 감소 현상은 선별·파쇄 공정을 거치면서 일부 지방성분을 함유한 물질들의 제 거와 예열과 멸균 공정을 거치면서 휘발성 지 방산의 손실에 비롯된 것으로 사료되었다. 섬 유소 성분의 감소 현상은 선별 - 파쇄 공정에서 덩어리가 큰 배추, 무, 야채 껍질들을 걸러내기 때문인 것으로 사료되었다.

$\mathrm{pH}$ 는 가공처리 전과 후에 비슷한 수치를 보 였으며, 처리에 따른 염분의 $9 \%$ 정도 감소 $(\mathrm{P}<$ $0.05)$ 현상은 가공과정에서 고염분 김치류 덩어 리의 제거로 인한 것으로 사료되었다. 여기서 도출된 염분의 함량으로만 볼 때, 습식 사료화 를 통해 생산된 음식물쓰레기의 염분이 매우 높아 단독으로는 이용이 불가능하며, 여기에 다른 사료들을 혼합할 때 염분의 충분한 희석 현상을 필수적으로 고려하여야 할 것으로 판단 되었다. 멸균 전과 비교해서 멸균, 발효 후의 액상발효물의 $\mathrm{Ca}(4.3 \%$ vs $3.0 \%)$ 과 $\mathrm{P}(0.87 \%$ vs
$0.61 \%$ )의 함량이 상대적으로 낮아진 이유는 선 별 - 파쇄공정을 거치면서 뼈 잔재물이 선별되 면서 $\mathrm{Ca}$ 과 $\mathrm{P}$ 의 함량이 낮아졌기 때문인 것으로 사료되었다. 처리 전과 후의 발효물 단백질의 pepsin 소화율은 각각 $77.3 \%, 78.8 \%$ (Table 미제 시)로서 차이가 없었다. 본 습식사료화 공정의 경우, 건조 사료화 방식과 비교하여 상대적으 로 낮은 온도에서 짧은 시간동안 열처리(예열 기에서 $80^{\circ} \mathrm{C} 20$ 분, 멸균기에서 $100^{\circ} \mathrm{C}$ 이하 10 분)하는 관계로 단백질 변성이나 피해가 미미 한 것으로 사료되었다.

멸균 전의 음식물쓰레기 원료와 멸균 및 발 효 후의 액상발효물의 아미노산 조성 차이는 Table 6에 제시되어졌다. 전반적으로 습식사료 화 공정은 음식물쓰레기 자체의 아미노산 함량 에 별다른 영향을 미치지 않았으며, lysine 함량 만이 유의적으로 감소하였다 $(\mathrm{P}<0.05)$. 결과적으 로 건조화 공정에서도 관찰된 바와 같이 lysine 은 열처리에 특히 민감한 것으로 판단되었다. 
Table 5. Chemical compositions(dry matter basis) of food waste before and after pasteurization for the liquid fermentation method $^{1)}$

\begin{tabular}{lccc}
\hline \multirow{2}{*}{ Item $^{2)}$} & \multicolumn{2}{c}{ Processing stage } & \multirow{2}{*}{ SE } \\
\cline { 2 - 3 } & $\begin{array}{c}\text { Before } \\
\text { pasteurization }\end{array}$ & $\begin{array}{c}\text { After pasteurization and } \\
\text { fermentation }\end{array}$ & \\
\hline \hline Dry matter (\%) & $19.9^{\mathrm{a}}$ & $16.9^{\mathrm{b}}$ & 0.5 \\
Organic matter (\%) & 84.8 & 86.0 & 0.7 \\
Crude protein (\%) & 22.1 & 22.5 & 0.3 \\
Neutral detergent fiber (\%) & 18.5 & 16.7 & 1.3 \\
Acid detergent fiber (\%) & 13.1 & 13.9 & 1.2 \\
Crude fiber (\%) & $6.3^{\mathrm{a}}$ & $5.9^{\mathrm{b}}$ & 0.1 \\
Nonfibrous carbohydrates (\%) & 27.2 & 30.7 & 3.9 \\
Ether extract (\%) & $18.9^{\mathrm{a}}$ & $15.2^{\mathrm{b}}$ & 1.3 \\
Nitrogen-free extract (\%) & 32.2 & 42.4 & 4.7 \\
Crude ash (\%) & 15.2 & 14.0 & 0.7 \\
Gross energy (Mcal/kg) & 5.024 & 4.885 & 0.097 \\
Digestible energy (Mcal/kg) & 3.972 & 3.826 & 0.079 \\
Metabolizable energy (Mcal/kg) & 3.807 & 3.708 & 0.076 \\
pH & 4.49 & 4.49 & 0.02 \\
NaCl (\%) & $5.16^{\mathrm{a}}$ & $4.40^{\mathrm{b}}$ & 0.18 \\
\hline
\end{tabular}

1) Means of 5 observations.

2) Digestible and metabolizable energy were calculated according to the equations of Noblet and Perez(1993) and May and Bell(1971), respectively.

${ }^{\mathrm{ab}}$ Means with different superscripts within the same row are significantly $\operatorname{different}(\mathrm{P}<0.05)$.

\section{3. 업체별 공정별 화학적 성분의 변화 비교}

세가지 가공처리 방법별 음식물쓰레기 또는 혼합물의 가공처리 전과 후의 영양소 손실율에 대한 결과는 Table 7에 제시되어져 있다. 음식 물쓰레기를 저수분 건식 방법으로 가공 처리함 에 따라 영양소의 손실율은 유기물 약 $12 \%$, 비 섬유성 탄수화물 약 $9 \%$, 조지방 약 $7 \%$, 무질소 화합물 약 $5 \%$ 등으로 상대적으로 변화가 미미 한 반건식 및 습식 발효 사료화 방법보다 훨등 히 높은 수치를 보였다 $(\mathrm{P}<0.05)$. 전반적으로 반건식 및 습식 발효 사료화 방법간의 영양소 손실율은 비슷하였으며 $(\mathrm{P}>0.05)$, 손실율도 미 미한 수준이었다. 에너지의 경우, 가소화 또는 대사성 에너지(돼지의 경우)의 손실율은 건식 $(24.5 \%)$, 반건식 $(8.1 \%)$, 습식 $(2.6 \%)$ 사료화 방법 의 순으로 높았다 $(\mathrm{P}<0.05)$.

\section{4. 가공처리 방법별 제기된 문제점과 개선 방안}

모든 처리 방법에 있어서 이물질 잔존 문제 는 공통적 현상이었으며, 특히 이용되는 가정 원 음식물쓰레기와 습식 사료화 방법에 있어서 문제는 심각한 수준이었다. 보다 완벽한 분리 수거 체계를 갖추어야 하며, 보다 뛰어난 선별 기의 개발이 요구되었다. 무엇보다 파쇄 과정 에서 발생될 수 있는 작은 입자의 병 조각은 선별이 매우 어렵기 때문에 특히 유의하여야 할 사항이다. 건식 사료화 방법에 있어서 건조 공정 중에 발생되는 영양소, 특히 에너지(가소 화 및 대사성 에너지)의 상당한 손실은 피할 수 없으며, 또한 열처리에 따른 단백질 성분의 상당한 질적 저하는 동물 급여 전에 양질의 에 너지 및 단백질 사료 보충을 필연적으로 요구 하고 있다.

반건식 발효 사료화 방식의 경우, rotary 
Table 6. Amino acid contents and pepsin digestibility of food waste before and after pasteurization for the liquid fermentation method ${ }^{1)}$

\begin{tabular}{|c|c|c|c|}
\hline \multirow[b]{2}{*}{ Item } & \multicolumn{2}{|c|}{ Processing stage } & \multirow[b]{2}{*}{$\mathrm{SE}$} \\
\hline & $\begin{array}{c}\text { Before } \\
\text { pasteurization } \\
\end{array}$ & $\begin{array}{l}\text { After pasteurization } \\
\text { and fermentation } \\
\end{array}$ & \\
\hline \multicolumn{4}{|c|}{ Essential amino acids } \\
\hline Lysine & $0.84^{\mathrm{a}}$ & $0.80^{\mathrm{b}}$ & 0.01 \\
\hline Methionine & 0.24 & 0.23 & 0.01 \\
\hline Threonine & 0.79 & 0.77 & 0.01 \\
\hline Isoleucine & 0.80 & 0.79 & 0.02 \\
\hline Valine & 0.95 & 0.95 & 0.01 \\
\hline Leucine & 1.37 & 1.35 & 0.02 \\
\hline Histidine & 0.86 & $0.92^{\mathrm{b}}$ & 0.01 \\
\hline Phenylalanie & 0.68 & 0.67 & 0.02 \\
\hline Arginine & 1.13 & 0.98 & 0.02 \\
\hline \multicolumn{4}{|c|}{ Non-essential amino acids } \\
\hline Aspartic acid & 1.79 & 1.72 & 0.03 \\
\hline Glutamic acid & 3.52 & 3.51 & 0.12 \\
\hline Serine & 0.85 & 0.81 & 0.01 \\
\hline Proline & 1.24 & 1.07 & 0.04 \\
\hline Glycine & 1.49 & 0.70 & 0.47 \\
\hline Alanine & 1.42 & 1.40 & 0.02 \\
\hline Tyrosine & 0.56 & 0.58 & 0.01 \\
\hline Cystine & 0.20 & 0.22 & 0.01 \\
\hline Total amino acids & 18.71 & 17.47 & 0.47 \\
\hline Pepsin digestibility & 77.3 & 78.8 & 3.4 \\
\hline
\end{tabular}

\footnotetext{
1) Based on dry matter.

ab Means with different superscripts within the same row are significantly $\operatorname{different}(\mathrm{P}<0.05)$.
}

drum 내에서의 멸균 처리 중 혼합물의 함수율 이 $50 \%$ 이상으로 높을 경우 혼합물이 작은 덩 어리로 뭉쳐지는 현상이 발생되는데 이를 극복 하기 위해서는 기기 내부를 기계적으로 보완하 거나, 함수율이 높은 음식물쓰레기의 혼합비율 을 낮추어야 하는 단점이 있었다. 최종 사료 제품의 영양 성분은 양호한 수준이라 하더라도 lysine 함량이 부족되기 쉽기 때문에 특히 주의 가 요망되었다. 그리고 최초 보조사료 혼합 시 동물 영양소 요구량을 충족시키는 과학적인 사 료 배합비 설계가 중요하였다. 또한 비싼 보조 사료 비용을 절감하기 위해서는 지역에서 발생 되는 부존사료자원을 최대한 이용하는 것이 바 람직할 것이다. 중수분 발효 사료를 중대규모 돈사의 자동 급이기 시스템에 적용할 때에 자
동 이송이 어려울 수 있는데 이때 발효사료를 건조, 펠렛화 하면 문제점을 극복할 수 있게 된다.

습식 발효 사료화 방식의 경우 비탈수로 인 한 높은 염분 농도는 동물에게는 직접적인 피 해가 없다 하더라도 음수량의 증가로 인해 돈 사 바닥이 쉽게 질척해져서 주위 환경이 불량 해지기 때문에 특히 신경을 써야 할 부분이며, 함수율 높은 사료를 먹이기 때문에 발생되는 적정 건물 섭취량의 한계로 인해 동물 성장 저 하 현상이 나타날 수 있기 때문에(NRC, 1998) 가능한 한 고영양성 사료를 보충하여야 함은 필수적이었다. 또한 이 방식은 농가에 적용 시, 대단위 농가에서는 자동시설 설치에 따라서 인 건비와 부대비용을 대체하는 효과가 있지만, 
Table 7. Differences in chemical contents(dry matter basis) of food waste or its mixture after processed by the dehydration, semi-dehydration fermentation and liquid fermentation methods ${ }^{1), 2)}$

\begin{tabular}{lcccccc}
\hline & \multicolumn{5}{c}{ Processing methods } \\
\cline { 2 - 7 } Item & $\begin{array}{c}\text { Dehyd- } \\
\text { ration }\end{array}$ & SD & $\begin{array}{c}\text { Semi-dehy- } \\
\text { dration }\end{array}$ & SD & Liquid & SD \\
\hline \hline Organic matter (\%) & $-11.52^{\mathrm{a}}$ & 9.62 & $0.10^{\mathrm{b}}$ & 0.90 & $1.24^{\mathrm{b}}$ & 1.58 \\
Crude protein (\%) & -2.14 & 2.33 & -0.08 & 0.53 & 0.18 & 0.82 \\
Neutral detergent fiber (\%) & $5.57^{\mathrm{a}}$ & 3.41 & $1.74^{\mathrm{ab}}$ & 5.42 & $-2.32^{\mathrm{b}}$ & 1.81 \\
Acid detergent fiber (\%) & $7.44^{\mathrm{a}}$ & 3.72 & $1.24^{\mathrm{b}}$ & 1.03 & $-0.18^{\mathrm{b}}$ & 0.91 \\
Crude fiber (\%) & $1.68^{\mathrm{a}}$ & 1.69 & $-0.34^{\mathrm{b}}$ & 0.26 & $-0.22^{\mathrm{b}}$ & 0.52 \\
Nonfibrous carbohydrates (\%) & $-8.89^{\mathrm{a}}$ & 6.53 & $0.50^{\mathrm{b}}$ & 1.82 & $7.11^{\mathrm{b}}$ & 3.47 \\
Ether extract (\%) & $-6.51^{\mathrm{a}}$ & 1.07 & $-0.06^{\mathrm{b}}$ & -0.79 & $-3.77^{\mathrm{a}}$ & 2.83 \\
Nitrogen-free extract (\%) & $-4.92^{\mathrm{a}}$ & 7.19 & $0.42^{\mathrm{ab}}$ & 0.98 & $4.05^{\mathrm{b}}$ & 4.41 \\
Crude ash (\%) & $11.88^{\mathrm{a}}$ & 9.27 & $0.08^{\mathrm{b}}$ & 0.96 & $-1.24^{\mathrm{b}}$ & 1.58 \\
Gross energy (Mcal/kg) & -0.679 & 0.614 & -0.275 & 0.478 & -0.048 & 0.074 \\
Digestible energy (Mcal $\left./ \mathrm{kg}^{3}\right)$ & $-0.840^{\mathrm{a}}$ & 0.482 & $-0.244^{\mathrm{ab}}$ & 0.485 & $-0.141^{\mathrm{b}}$ & 0.175 \\
Metabolizable energy (Mcal/ $\left./ \mathrm{kg}^{3}\right)$ & $-0.810^{\mathrm{a}}$ & 0.475 & $-0.257^{\mathrm{ab}}$ & 0.482 & $-0.099^{\mathrm{b}}$ & 0.169 \\
\hline I) & & & & & &
\end{tabular}

\footnotetext{
1) Means of 5 observations.

2) Differences were determined before and after processing food waste alone for dehydration and liquid fermentation methods and before and after processing food waste mixture for semi-dehydration fermentation method.

3) Digestible and metabolizable energy were calculated according to the equations of Noblet and Perez(1993) and May and Bell(1971), respectively.

abc Means with different superscripts within the same row are significantly $\operatorname{different}(\mathrm{P}<0.05)$.
}

중·소 농가에서는 시설비에 소요되는 자본의 부담이 생산비에 영향을 미칠 우려가 있었다.

$$
\text { IV. 요 약 }
$$

본 연구는 음식물쓰레기의 건식 건조, 반건 식 발효, 습식 발효 사료화 방법별로 대표적 업체를 방문하여 사료 제조 공정을 조사-소개 하고, 사료화 방법별 공정별 음식물쓰레기의 물리화학적 성분을 추적하고, 영양소 손실율을 비교.평가하며, 사료화 방법별 문제점을 발굴 하여 이의 개선 방안을 최종적으로 제시하기 위하여 실시하였다. 건식 사료화 방법의 경우, 탈수 공정은 원료 음식물쓰레기의 수분 $(10 \%$ 정 도) 및 조지방 성분을 감소시키고 $(\mathrm{P}<0.05)$, 섬 유소( $\mathrm{NDF}, \mathrm{ADF}$, 조섬유소) 성분을 증가시켰다 $(\mathrm{P}<0.05)$. 탈수·건조 공정은 원료 음식물쓰레 기의 조지방과 필수아미노산 중 lysine, methionine, histidine 성분을 줄이고 $(\mathrm{P}<0.05)$, 단백질
의 pepsin 소화율을 반 정도로 감소시켰으며 $(\mathrm{P}$ $<0.05)$, 섬유소, 조회분, $\mathrm{Ca}, \mathrm{P}$ 성분은 증가시켰 다 $(\mathrm{P}<0.05) . \mathrm{pH}$ 는 차이가 없었으나 $(\mathrm{P}>0.05)$, 염 분은 $40 \%$ 이상 감소하였다 $(\mathrm{P}<0.05)$. 반건식 발 효사료화 방법은 음식물쓰레기 혼합물의 일반 조성분, 단백질의 pepsin 소화율, 에너지 성분, $\mathrm{pH}$ 및 염분 농도에 별다른 영향을 미치지 않 았다 $(\mathrm{P}>0.05)$. 습식 발효사료화 방법의 경우, 멸균 전과 비교해서 멸균·발효 후에는 건물, 조지방, 조섬유소, lysine 성분이 감소하였으나 $(\mathrm{P}<0.05)$, 그 외의 일반 조성분, 단백질의 pepsin 소화율 및 $\mathrm{pH}$ 에는 차이가 없었다 $(\mathrm{P}>0.05)$. 염 분(5.16 vs $4.40 \%)$ 은 $9 \%$ 정도 감소하였다 $(\mathrm{P}<$ 0.05). 사료화 방법 중 건식 사료화 방법은 영 양소 손실율(대사성에너지 $24 \%$, 유기물 $12 \%$ 등 $)$ 이 가장 높았으며 $(\mathrm{P}<0.05)$, 반건식 및 습식 발효 사료화 방법은 미미한 영양소 손실을 보 여주었다. 현장 업체 방문 조사 결과, 특히 아 파트원 음식물쓰레기의 사료화 시 모든 처리 
방법들 공히 제품에의 이물질 잔존 문제는 공 통적으로 나타났으며, 완벽한 선별기의 개발이 요구되었다. 건식 사료화시 열처리에 따른 상 당한 에너지 성분 감소와 단백질의 질적 저하 는 다른 사료와의 배합비 설계시 양질의 에너 지 및 단백질 사료의 보충을 필요로 하였다. 반건식 발효 사료화의 경우, 보조 사료와의 혼 합시 과학적인 사료 배합비 설계가 요구되었 다. 습식 발효 사료화 방법의 경우, 고수분 사 료의 공급으로 인한 동물의 건물 섭취량 제한 현상으로 초래되는 동물 성장 저하 문제를 극 복하기 위해서는 가능한 한 고영양성 사료를 보충하여야 할 것으로 사료되었다.

\section{V. 인 용 문 헌}

1. AOAC. 1990. Official Methods of Analysis (15th Ed.). Association of Official Analytical Chemists, Washington, D. C., USA.

2. Barth, K. M., Vander Noot, G. W., MacGrath, W. S. and Kornegay, E. T. 1966. Nutritive value of garbage as a feed for swine. II. mineral content and supplementation. J. Anim. Sci. 25:52-57.

3. Chae, B. J., Choi, S. C., Kim, Y. G., Kim, C. H. and Sohn, K. S. 2000. Effects of feeding dried food waste on growth and nutrient digestibility in growing-finishing pigs. Asian-Australasian J. Anim. Sci. 13(9):1304-1308.

4. Fiske, C. H. and Subbarow, Y. 1925. The colorimetric determination of phosphorus. J. Biol. Chem. 66:375-400.

5. Kwak, W. S. and Kang, J. S. 2005. Effect of feeding food waste-broiler litter and bakery byproduct mixture to pigs. Bioresource Technology 96:in press.

6. May, R. W. and Bell, J. M. 1971. Digestible and metabolizable energy values of some feeds for the growing pig. Can. J. Anim. Sci. 51:271-278.

7. Myer, R. O., Brendemuhl, J. H. and Johnson, D. D. 1999. Evaluation of dehydrated restaurant food waste products as feedstuffs for finishing pigs. J. Anim. Sci. 77:685-692.

8. National Research Council. 1998. Nutrient Requirements of Swine (10th rev. ed.). National Academy Press. Washington, D. C., USA.

9. Noblet, J. and Perez, J. M. 1993. Prediction of digestibility of nutrients and energy values of pig diets from chemical analysis. J. Anim. Sci. 71:3389-3398.

10. Statistix7. 2000. User's Manual. Analytical Software, Tallahassee, FL, USA.

11. U.S. Congress. 1980. Swine Health Protection Act.
Public Law 96-468, USA.

12. Van Soest, P. J. 1987. Nitrogen metabolism. In Nutritional Ecology of the Ruminant. Cornell University Press, Ithaca, New York, pp. 230-248.

13. Van Soest, P. J., Robertson, J. B. and Lewis, B. A. 1991. Methods of dietary fiber, neutral detergent fiber, and nonstarch polysaccharides in relation to animal nutrition. J. Dairy Sci. 74:3583.

14. Westendorf, M. L., Dong, Z. C. and Schoknecht, P. A. 1998. Recycled cafeteria food waste as a feed for swin: nutrient content, digestibility, and meat quality. J. Anim. Sci. 76:2976-2983.

15. Westendorf, M. L. 2000. Food waste as animal feed: An introduction. In: Food Waste to Animal Feed (Ed.), Iowa State University Press, Ames, Iowa, USA.

16. 곽완섭, 강준석, 백용현, 지경수, 배지선, 김영일. 2004. 남은음식물의 양돈전용 완전발효사료화 기 술. 제 8 회 심포지움: 폐자원 재활용 방향과 이용 기술 pp. 133-159. 한국폐자원사료화학회, 2004. 10. 28. 농촌진흥청 농촌자원개발연구소.

17. 남병섭, 정일병, 김영화, 문홍길, 김동훈, 허상만, 배인휴, 양철주. 2000. 남은음식물 사료가 육성비 육돈의 성장과 도체특성에 미치는 영향. 한국동 물자원과학회지 42(3):279-288.

18. 노경상. 2001. 남은음식물에 대한 안전관리 제도. 5th 심포지움, 남은음식물 안전 사료화 이용기술, 축산기술연구소, 수원.

19. 농림부. 2001. 유해사료의 범위와 기준. 농림부고 시 제2001-61호, 2001.10.5.

20. 서희동. 1998. 음식물찌꺼기의 가축사료화. 남은 음식물 사료화 심포지움. 음식물찌꺼기사료화연 구회, 축산기술연구소, 1998.2.4. 수원.

21. 소만호. 1999. 남은음식물 사료화를 위한 추진상황 및 대책. 남은음식물 사료화 심포지엄. 남은음식물 사료화연구회, 축산기술연구소, 1999. 7. 2. 수원.

22. 이기영. 1998. 음식물찌꺼기 사료화를 위한 발효기 술 개발. 남은음식물 사료화 심포지엄. 음식물찌꺼 기사료화연구회, 축산기술연구소, 1998. 2. 4. 수원

23. 정완태, 이병석, 신기준, 차영호, 이왕식, 이성실. 1999. 남은음식물 사료의 가축이용 기술. 남은음 식물 사료화 심포지움. 남은음식물사료화연구회, 축산기술연구소, 1999. 7. 2. 수원.

24. 정우진, 손영옥, 임계택, 김용웅, 김태환. 2001. 남은 음식물의 고온숙성 발효 사료가 돼지의 성 장 및 사료효율에 미치는 영향. 한국환경농학회 지 20(2):122-126.

25. 정재춘. 2001. 유기성폐기물의 자원화 현황 및 전망 : 음식물쓰레기의 재활용 활성화 전략. 한국 폐기물학회지 18(8):22-29.

26. 환경부. 2004. 2003 전국 폐기물 발생 및 처리 현황. 국립환경연구원, 환경부.

(접수일자 : 2005. 3. 29. / 채택일자 : 2005. 7. 4.) 